\title{
Leptin Level and Plasma Prothrombotic Factors in Obese Subjects
}

\author{
${ }^{(1)}$ Hamdia Ezzat, ${ }^{(2)}$ Eman M Abd El-Rahman, \\ ${ }^{\text {(2) }}$ Sabilah G Mousa, and Eman A Mahmoud ${ }^{(3)}$ \\ ${ }^{(1)}$ Clinical Pathology $\&{ }^{(2)}$ Internal Medicine and ${ }^{(3)}$ Rheumatology \& Rehabilitation \\ Departments, Al-Azhar and Assiut University
}

\begin{abstract}
:
Obesity is associated with increased cardiovascular morbidity and mortality. Abnormalities in coagulation and haemostasis represent a well-known link between obesity and thrombosis (both arterial and venous).

In human, production of a depocyte-derived peptide, leptin has been linked to adiposity; recent studies have shown that plasminogen activator inhibitor-1 (PAI-1), a prothrombotic factor associated with atherosclerosis complication is also produced in adipose tissue.

Several studies reported that obese subjects had elevated levels of vonWillbrand factor (vWF) and fibrinogen .

The aim of this work is to examine the relationship of obesity, fat distribution and serum leptin concentration with plasma levels of Prothrombotic factors (PAI-1 - (vWF) and fibrinogen) and lipid pattern (Triglycerides and Cholesterol) as metabolic parameters.

The body fat distribution was evaluated by measuring the body mass index ( BMI) and waist-tohip ratio (WHR).

This study was carried out on four groups:

Group I (Control Group): Which is subdivided into two groups:

Group Ia: Consists of 10 apparently healthy normal females with BMI $\leq 25 \mathrm{~kg} / \mathrm{m}^{2}$.

Group Ib: Consists of 10 apparently healthy normal males with BMI $\leq 25 \mathrm{~kg} / \mathrm{m}^{2}$.

Group II (Female Obese): 16 obese females with BMI $\geq 30 \mathrm{~kg} / \mathrm{m}^{2}$.

Group III (Male Obese): 16 Obese males with BMI $\geq 30 \mathrm{~kg} / \mathrm{m}^{2}$.
\end{abstract}

Results can be summarized as follows:

1. Very highly significant increase in serum leptin levels in group II and III vs group I $(\mathrm{P}<0.0001)$. Serum leptin was increased non-significantly in female group than male group $(\mathrm{P}>0.05)$.

2. Highly significant increase in serum concentration of cholesterol and triglycerides levels in group II and III vs group I.

3. Obese subjects (group II and group III) had higher plasma concentration of all prothrombotic factors as compared to lean groups (GI) . PAI- $1 \mathrm{P}<0.0001$ for both obese groups, vWF and fibrinogen, $\mathrm{P}<0.001$ for both obese groups.

4. Significant increase in plasma levels of both PAI-1 and fibrinogen in female obese as compared to male obese $(\mathrm{P}<0.05)$. Plasma level of vWF was increased nonSignificantly in female obese than male obese $(\mathrm{P}>0.05)$.

There was significant positive correlation between BMI and WHR, also there was a significant positive correlation between both of them and serum leptin concentration, plasma PAI-1, vWF and fibrinogen in groups II and group III.

- WHR are positively associated with serum cholesterol and triglycerides in group II and group III.

- There was significant positive correlation between leptin concentration and plasma PAI$1, \mathrm{vWF}$, fibrinogen, cholesterol and triglycerides in both obese groups. 
- There was significant positive correlation between PAI-1 and vWF, also there was significant positive correlation between both of them and fibrinogen in group II and group III.

- There was significant positive correlation between serum triglycerides and PAI-1 in both obese groups.

In conclusion: Increased body fat mainly (abdominal fat) are associated with increased concentrations of cardiovascular risk factors. Plasma concentration of the prothrombotic factors are increased in obese subjects as compared to non-obese controls, leptin seems to be involved in this elevation and emerges as a predictor of circulating PAI-1, vWF and fibrinogen concentration. Increased PAI-1 expression in obese subjects can direct influence vessel wall remodeling and play an important role in the development of athrothrombosis by decreasing fibrin degradation.

\section{Introduction}

Obesity is associated with increased cardiovascular morbidity and mortality (Pascual et al., 2003 and Lowenstein et al., 2004). Adipocytes are the sites where triglycerides are stored or free fatty acids are released, depending on the body's energy demands (Cianflone et al., 1995).

In addition, adipocytes produce several mediators; one of them is leptin, the product of the obese gene that might regulate body weight signaling the amount of body fat (Maffei et al., 1995).

Recently, production of PAI-1 by adipose tissue, in particular by fat from omentum have evidenced and it has been proposed that it could be responsible for the elevated plasma PAI-1 level observed in insulin resistance Diabetes (Juhan-Vague et $a l$.,and 2000Mavri et al., 2001). This tissue also produces several effector molecules that can up regulate PAI-1. these molecules include transforming growth factor beta, tumor necrosis factor alpha, angiotensin II and interleukin-6, all of which up regulate PAI-1 in various cell types (Mutch et al., 2001).

Obese patients have higher plasma concentrations of all prothrombotic factors (fibrinogen, vWF and factor VII) as compared to non-obese control with a positive association with central fat (De Pergola et al., 2002). Furthermore, obesity is characterized by higher plasma concentration of antithrombotic factors such as tissue type plasminogen activator (t-PA) and protein $\mathrm{C}$, as compared to nonobese controls, the increase in these factors being likely to represent a protective response counteracting the increase in prothrombotic factors (De Pergola et al., 1997).

The aim of this work is to determine the relationship of obesity, fat distribution, serum leptin concentration with the plasma levels of prothrombotic factors (PAI-1, vWF and Fibrinogen) and lipid pattern (triglycerides and cholesterol) as metabolic parameters.

\section{Patients\& Methods}

The present work was carried out on 52 subjects. They were divided into four groups:

Group I : Consisted of 20 apparently healthy normotensive, non-smoker and nondiabetic hospital workers or their relatives. This group was further subdivided into:

Group Ia: Consist of 10 normal healthy lean females with an age ranged from 25-43 years (mean 35 years) and their BMI ranged from 20.7-25 with mean of $23.1 \mathrm{~kg} / \mathrm{m}^{2} \pm 2$ and WHR ranged from $0.70-0.85$ with a mean of $0.8 \pm 0.05$.

Group Ib: Consisted of 10 normal healthy lean males with an age ranged from 24-44 years (mean 36 years) and their BMI ranged from 22-25 with mean of $24.5 \mathrm{~kg} / \mathrm{m}^{2} \pm 1.3$ and WHR ranged from $0.8-0.94$ with a mean of $0.89 \pm 0.1$.

Group II: Consisted of 16 obese females with an age ranged from 26-40 years (mean 


\section{Hamdia Ezzat et al}

of 34 years) and their BMI ranged from 30.1 - 36.8 with a mean of $33.4 \mathrm{~kg} / \mathrm{m}^{2} \pm$ 1.78 and WHR ranged from 0.9-1.2 with a mean of $1.05 \pm 0.1$.

Group III: Consisted of 16 obese male with age ranged from 27-42 years (mean 35.5 years) and their BMI ranged from $31.5-37.7 \mathrm{~kg} / \mathrm{m}^{2}$ with a mean of 35.7 $\mathrm{kg} / \mathrm{m}^{2} \pm 2.4$ and WHR ranged from $0.99-1.2$ with a mean of $1.19 \pm 0.109$.

All of the studied subjects were none diabetic normotensive, none had cardiovascular complications or any previous history of pulmonary disease non suffering from any chronic or acute disease, none taking any drug that could affect the coagulation test. None of the females was receiving oral contraceptives and pregnant females were excluded. Smoker and subjects with endocrine disease were excluded.

All the 52 persons were subjected to the following:

i. Detailed physical examination to exclude endocrine and cardiac comorbidities.

ii. BMI Calculation: Height and weight were measured and the BMI were calculated by a simple mathematical equation by dividing weight $(\mathrm{kg}) /$ height $^{2}\left(\mathrm{~m}^{2}\right)$. The normal range of BMI $\quad\left(19.1-25 \quad \mathrm{~kg} / \mathrm{m}^{2}\right)$ (Karl and Hymsfield, 1987).

iii. WHR Calculation: The waist circumference and hip circumference was measured at the level of umbilicus "minimal waist girth" and the symphysis pubis (maximal hip girth) respectively. Then the waist/hip ratio was calculated by dividing the waist circumference/hip circumference (Karl and Hymsfield, 1987).

iv. Laboratory Investigation: From each subject $10 \mathrm{ml}$ blood were collected, blood was divided as follows:

1. Two ml were collected into tube containing dipotassium EDTA, used for complete blood count by (fully automated blood counter "Coulter T660").

2. Four ml were collected into a plain tube, and allowed to clot .Serum was divided into 3 aliquots, one tube were stored at $-20^{\circ} \mathrm{C}$ for measurement of serum leptin, and the other two tubes were ready for:

a. Routine chemistry tests: Kidney function tests (serum creatinine and urea), liver function tests (AST, ALT, T.Bil \& ALP), and fasting blood glucose were determined using fully automated chemistry analyzer (Hitachi 911) to exclude other systemic disease.

b. Lipid profile included serum levels of total cholesterol (TC), and triglycerides (TG) were performed using commercial kits from Boerhinger Mannheim.

\section{Measurments of serum leptin (Akira et al., 1997):}

Serum leptin was measured by using enzyme linked immunosorbent assay, (ELISA) kit, supplied from diagnostic system laboratories Inc (DSL). The assay is based on an oligoclonal system in which a blend of monoclonal antibodies (MAbs) directed against human leptin are used.

Standard or sample containing serum leptin react with capture monoclonal antibodies (antihuman leptin antibody) coated on the microtitre well, after incubation and washing the wells were treated with antibody enzyme conjugate solution (antihuman leptin detection antibody labeled with horseradish peroxidase "HRP").

After an incubation period allowing the formation of a sandwich, the microtiter plate is washed to remove unbound enzyme labeled antibodies. Then the well were incubated with substrate tetramethyle benzidine (TMB) for 10 minutes.

An acidic stopping solution was then added and the amount of enzymatic turnover is determined colourmetrically by measuring the absorbance which is proportional to serum leptin concentration in the sample.

3. We added $3.6 \mathrm{ml}$ of blood to $0.4 \mathrm{ml}$ of trisodium citrate $(3.8 \%)$, mixed well and kept on Ice until centrifuged. The sample was centrifuged for 15 minutes at $3000 \mathrm{~g}$ and at temperature of $4^{\circ} \mathrm{C}$ to prepare platelet poor plasma with 
minimal platelet activation for the estimation of prothrombotic factors.

a. Fibrinogen was done immediately by using fully automated coagulation analyzer (sysmex dade Behering coagulation analyser).

The rest of the plasma was kept in 2 Eppendorph plastic tubes and stored immediately at $-20^{\circ} \mathrm{C}$ for a period not more than one month (until all blood sample were collected) and was used later for estimation of both PAI-1 and vWF.

Measurement of plasminogen activator inhibitor-1 (PAI-1) (Booth et al., 1988):

Immunobind plasma PAI-1 ELISA kit from American diagnostic, USA is a commercial ELISA kit used for quantitative determination of human PAI-1 antigen based on sandwich technique.

Measurement of von Willebrand factor by READs, (Corgenis, Inc.) (Blann and McCllum, 1994):

READs vWF Ag assay is a sandwich ELISA.

\section{Statistical Analysis:}

All values were statistically analyzed through IBM computer using CSS/PC; Basic state, descriptive statistics. Such as means and standard deviation were used for numerical variables.

Comparison of the value was performed using paired student's T-test and the two tailed P-value.

Regression analysis was performed to evaluate the correlation among the different parameters using spearman correlation coefficient $(\mathrm{r}) . \mathrm{P}$ is considered significant when it is < 0.05) (Sendecor and Cochran, 1968).

\section{Results:}

Table (1) shows that, obese subjects group II and group III had a highly significant elevation in weight, BMI, and
WHR as compared to normal control groups (group Ia \& group Ib).

Table (2) shows that, there is highly significant increase in serum cholesterol and triglyceride levels in group II and group III as compared to normal lean subjects. No significant difference were noted in the level of cholesterol or triglyceride when compared female obese to male obese.

Serum leptin was significantly very high in obese subjects as compared to lean subjects. Serum leptin was increased nonsignificantly in group II as compared to group III.

Plasma PAI-1, vWF $\mathrm{Ag}$ and fibrinogen were significantly very high in obese subjects (group II \& group III) when compared to lean subjects (group Ia \& group Ib).

There were significant increase in PAI-1 and fibrinogen levels when compared group II (female obese) to group III (male obese).

Non-significant increase in $\mathrm{vWF} \mathrm{Ag}$ was noticed in obese female as compared to obese male.

Tables $(3 \& 4)$ show that there were a significant positive correlation between BMI and WHR in group II and group III. Also, there was a significant positive correlation between both of them and serum leptin concentration, plasma PAI-1, vWF $\mathrm{Ag}$ and fibrinogen in group II and group III. WHR was positively correlated with serum cholesterol and triglycerides in female and male obese.

There was no correlation between BMI and cholesterol or triglycerides in obese groups.

Tables $(5 \& 6)$ show that serum leptin concentration was positively correlated with plasma levels of PAI-1, vWF, fibrinogen cholesterol and triglycerides in both obese group.

Plasma PAI-1 level was positively correlated with vWF, fibrinogen and triglycerides in both obese group.

Positive correlation was found between plasma vWF and fibrinogen in both obese group. 


\section{Hamdia Ezzat et al}

Table (1): Statistical comparison (mean \pm SD) of weight, height, BMI and WHR in different studied groups.

\begin{tabular}{|c|c|c|c|c|c|c|c|}
\hline \multirow[t]{2}{*}{ Variables } & $\begin{array}{c}+ \text { control } \\
\text { Group la } \\
(\mathbf{n}=10)\end{array}$ & $\begin{array}{l}\text { control } \\
\text { Group Ib } \\
(\mathrm{n}=10)\end{array}$ & $\begin{array}{l}\text { Obese } \\
\text { Group II } \\
(n=16)\end{array}$ & $\begin{array}{c}\text { Obese } \\
\text { Group III } \\
(n=16)\end{array}$ & $\begin{array}{c}\text { Group II } \\
\text { vs Group } \\
\text { la }\end{array}$ & $\begin{array}{c}\text { Group III } \\
\text { vs Group } \\
\text { Ib }\end{array}$ & $\begin{array}{c}\text { Group II } \\
\text { vs Group } \\
\text { III }\end{array}$ \\
\hline & $\underset{\text { SD }}{\operatorname{Mean} \pm}$ & $\underset{\text { SD }}{\operatorname{Mean} \pm}$ & $\underset{\text { SD }}{\operatorname{Mean} \pm}$ & $\underset{\text { SD }}{\operatorname{Mean} \pm}$ & P-value & P-value & P-value \\
\hline Weight (kg) & $62.6 \pm 4$ & $72 \pm 6.5$ & $\begin{array}{c}82.3 .6 \pm \\
7.4\end{array}$ & $\begin{array}{c}97.8 \pm \\
10.2\end{array}$ & $<0.001$ & $<0.001$ & $<0.01$ \\
\hline $\begin{array}{l}\text { Height } \\
\text { (meter) }\end{array}$ & $\begin{array}{c}1.52 \pm \\
0.04 \\
\end{array}$ & $\begin{array}{c}1.68 \pm \\
0.09 \\
\end{array}$ & $\begin{array}{c}1.56 \pm \\
0.05\end{array}$ & $\begin{array}{l}1.65 \pm \\
0.058 \\
\end{array}$ & $>0.05$ & $>0.05$ & $<0.01$ \\
\hline BMI $\left(\mathrm{kg} / \mathrm{m}^{2}\right)$ & $23.1 \pm 2$ & $24.5 \pm 1.3$ & $\begin{array}{c}33.4 \pm \\
1.78\end{array}$ & $35.7 \pm 2.4$ & $<0.0001$ & $<0.0001$ & $<0.05$ \\
\hline $\begin{array}{c}\text { Waist/hip } \\
\text { ratio }\end{array}$ & $0.8 \pm 0.05$ & $0.89 \pm 0.1$ & $1.05 \pm 0.1$ & $1.19 \pm 0.1$ & $<0.0001$ & $<0.0001$ & $>0.05$ \\
\hline
\end{tabular}

$P>0.05$ : Insignificant. $\quad P<0.001$ : Highly significant.

$\mathrm{P}<0.05$ : Significant. $\quad \mathrm{P}<0.0001$ : Very highly significant.

Table (2): Statistical comparison (mean \pm SD) of laboratory data in different studied groups.

\begin{tabular}{|c|c|c|c|c|c|c|c|}
\hline \multirow{2}{*}{ Variables } & $\begin{array}{l}\text { control } \\
\text { Group la } \\
(n=10)\end{array}$ & $\begin{array}{l}\text { control } \\
\text { Group lb } \\
(n=10)\end{array}$ & $\begin{array}{l}\text { Obese } \\
\text { Group II } \\
(n=16)\end{array}$ & $\begin{array}{l}\text { Obese } \\
\text { Group III } \\
(n=16)\end{array}$ & $\begin{array}{l}\text { Group II } \\
\text { vs Group } \\
\text { la }\end{array}$ & $\begin{array}{l}\text { Group III } \\
\text { vs Group } \\
\text { lb }\end{array}$ & $\begin{array}{l}\text { Group II } \\
\text { vs Group } \\
\text { III }\end{array}$ \\
\hline & $\begin{array}{l}\text { Mean } \pm \\
\text { SD }\end{array}$ & $\begin{array}{l}\text { Mean } \pm \\
\text { SD }\end{array}$ & $\begin{array}{l}\text { Mean } \pm \\
\text { SD }\end{array}$ & $\begin{array}{l}\text { Mean } \pm \\
\text { SD }\end{array}$ & P-value & P-value & P-value \\
\hline $\begin{array}{l}\text { Cholesterol } \\
\text { (mg/dL) }\end{array}$ & $\begin{array}{l}175 \pm \\
13.2\end{array}$ & $\begin{array}{l}178 \pm \\
15.5\end{array}$ & $\begin{array}{l}245.9 \pm \\
46\end{array}$ & $\begin{array}{l}249 \pm \\
37.8\end{array}$ & $<0.001$ & $<0.001$ & $>0.05$ \\
\hline $\begin{array}{l}\text { Triglycerides } \\
\text { (mg/dL) }\end{array}$ & $110 \pm 20$ & $113 \pm 18$ & $\begin{array}{l}170.8 \pm \\
12.1\end{array}$ & $170.3 \pm 14$ & $<0.001$ & $<0.001$ & $>0.05$ \\
\hline Leptin (ng/mL) & $8.37 \pm 2.5$ & $7.9 \pm 2.1$ & $29.5 \pm 4.9$ & $27.3 \pm 5.1$ & $<0.0001$ & $<0.0001$ & $>0.05$ \\
\hline PAl-1 (ng/mL) & $27.9 \pm 8.2$ & $24.5 \pm 7.9$ & $59 \pm 12.8$ & $50.4 \pm 6.9$ & $<0.0001$ & $<0.0001$ & $>0.05$ \\
\hline $\begin{array}{l}\text { vWF Ag } \\
\text { (ng/mL) }\end{array}$ & $\begin{array}{l}105 \pm \\
11.5\end{array}$ & $98 \pm 1$ & $\begin{array}{l}144 \pm \\
19.2\end{array}$ & $\begin{array}{l}137.8 \pm \\
12\end{array}$ & $<0.0$ & $<0$ & 5 \\
\hline $\begin{array}{l}\text { Fibrinogen } \\
\text { (mg/dL) }\end{array}$ & $\begin{array}{l}210 \pm \\
21.3\end{array}$ & $203 \pm 22$ & $\begin{array}{l}324 \pm \\
74.3\end{array}$ & $\begin{array}{l}282 \pm \\
38.6\end{array}$ & $<0.001$ & $<0.001$ & $<0.05$ \\
\hline
\end{tabular}

$P>0.05$ : Insignificant.

$P<0.05$ : Significant.

$\mathrm{P}<0.001$ : Highly significant.

$\mathrm{P}<0.0001$ : Very highly significant.

Table (3): Correlation between WHR and BMI with different laboratory parameter in obese female (group II).

\begin{tabular}{|l|l|l|}
\hline & WHR & BMI \\
\cline { 2 - 3 } & R & R \\
\hline BMI & 0.351 & --- \\
\hline Leptin & 0.61 & 0.513 \\
\hline PAl-1 & 0.622 & 0.532 \\
\hline vWF & 0.709 & 0.573 \\
\hline Fibrinogen & 0.335 & 0.325 \\
\hline Cholesterol & 0.332 & 0.148 \\
\hline Triglycerides & 0.41 & 0.04 \\
\hline
\end{tabular}

$\mathrm{P}^{*} \leq 0.05$ 
Table (4): Correlation between WHR and BMI with different laboratory parameter in obese male (group III).

\begin{tabular}{|l|l|l|}
\hline \multirow{2}{*}{ BMI } & WHR & BMI \\
\cline { 2 - 3 } & $\mathbf{R}$ & $\mathbf{R}$ \\
\hline Leptin & 0.392 & --- \\
\hline PAI-1 & 0.81 & 0.63 \\
\hline vWF & 0.68 & 0.378 \\
\hline Fibrinogen & 0.336 & 0.31 \\
\hline Cholesterol & 0.365 & 0.549 \\
\hline Triglycerides & 0.35 & 0.258 \\
\hline
\end{tabular}

Table (5): Correlation between different laboratory parameters in obese female (group II).

\begin{tabular}{|l|l|l|l|l|l|}
\hline & Leptin vs & PAI-1 vs & vWF vs & Fibrinogen vs & Cholesterol vs \\
\cline { 2 - 6 } & R & R & R & R & R \\
\hline PAl-1 & 0.825 & & & & \\
\hline vWF & 0.829 & 0.87 & & & \\
\hline Fibrinogen & 0.554 & 0.637 & 0.404 & & \\
\hline Cholesterol & 0.324 & 0.207 & 0.249 & 0.207 & \\
\hline Triglycerides & 0.325 & 0.339 & 0.03 & 0.01 & 0.03 \\
\hline
\end{tabular}

$\mathrm{P}^{*}$ significant if $\leq 0.05$

Table (6): Correlation between different laboratory parameters in obese male (group III).

\begin{tabular}{|l|l|l|l|l|l|}
\hline & Leptin vs & PAl-1 vs & vWF vs & Fibrinogen vs & Cholesterol vs \\
\cline { 2 - 6 } & R & R & R & R & R \\
\hline PAl-1 & 0.732 & & & & \\
\hline vWF & 0.399 & 0.87 & & & \\
\hline Fibrinogen & 0.562 & 0.637 & 0.361 & & \\
\hline Cholesterol & 0.351 & 0.184 & 0.09 & 0.247 & \\
\hline Triglycerides & 0.338 & 0.392 & 0.179 & 0.047 & 0.368 \\
\hline
\end{tabular}

$\mathrm{P}^{*}$ significant if $\leq 0.05$

\section{Discussion:}

Obesity is the most common and costly nutritional problem affecting approximately $33 \%$ of adults (Kuczmarski et al., 1994). A body mass index greater than 28 is associated with a risk of morbidity. Such as stroke, ischemia, heart disease or diabetes mellitus, that is four times the risk in the general population (Naveau et al., 1997 and Poirier \& Despres, 2003).

In this study there was very highly significant increase in serum leptin levels in obese subjects $(\mathrm{P}<0.0001)$ for both female and male groups as compared to the control groups. Serum leptin was increased nonsignificantly in female obese than male obese $(P>0.05)$. Also, there were nonsignificant increase in serum leptin in female control group as compared to male control group.

These results are in agreement with that of Liuzzi et al., (1999); Soderberg et al. (1999) and Miller et al. (2001). This is because leptin impairs several metabolic effects on insulin as stimulation of glucose transport, glycogen synthesis, lipogenesis and protein kinase A activation as well as stimulation of protein synthesis. At low leptin concentrations, insulin sensitivity is increased. At higher concentration, the insulin responsiveness is diminished resulting in nearly complete inhibition of its effect at high leptin level. Thus leptin may be related to the pathophysiology of insulin resistance in both NIDDM and obesity (Hanque and Rahman, 2003). 


\section{Hamdia Ezzat et al}

Porreca et al. (2004) agreed with us that obese women had higher levels of leptin than healthy control. They also reported that obesity is associated with enhanced levels of atherosclerosis markers. These abnormalities are related to abdominal obesity possibly mediated by leptin levels and are reversible with weight loss.

Leptin concentrations showed a direct correlation with BMI in both sexes. These results are in agreement with that of Liuzzi et al. (1999) and Soderber et al. (1999). Leptin concentration showed a direct correlation with WHR. These results disagreement with that of Liuzzi et al., (1999) who reported inverse correlation between leptin and WHR.

In this work, there was a significant increase in plasma PAI-1 levels in obese female and male groups as compared to normal control groups. These results were in agreement with that of Mavri et al., (2001) and Romano et al. (2003). Mavri et al. (2001)reported that only abdominal but not femoral subcutaneous fat were associated with increased in plasma PAI-1 in obese male and female.

In the present study, there was a significant positive correlation between PAI-1 and WHR in both obese group while Kockx et al. (1999) reported a relationship between visceral fat and PAI-1 in obese men but not in obese women.

In present study, plasma PAI-1 was associated with serum leptin; this results was in agreement with that of Sudi et al. (2000). They also, reported that adiposity and other variables contribute to higher levels of PAI-1. Leptin seems to be, independently linked with fibrinolytic parameters, the unfavorable metabolic and fibrinolytic risk profile might emanate from the obese pubertal stage.

In the present study, there was a significant positive correlation between PAI-1 and triglycerides. These results were in agreement with that of Sundell et al. (1988).

Our results showed that (vWF) were elevated in obese women and obese men; as compared to control groups (group Ia \& group Ib).Weyer et al. (2002) agreed with us,adding that obesity and insulin resistance appear to be associated with low-grade inflammation and endothelial dysfunction.

Guagnono et al. (2003) agreed with us in that obese women had significantly higher levels of leptin and vWF compared to healthy women.They also agreed with our results which showed that leptin were associated with vWF. They reported that leptin, might be a link between obesity and increased morbidity for cardiovascular disease. Leptin exerts proinflammatory, pro-angiogenic actions by activating a specific receptor (ob-Rb) which is expressed in human endothelial cells. Thus, a link may exist between leptin expression and endothelial dysfunction.

In the present work there was a significant increase in plasma fibrinogen levels in obese female and male groups as compared to normal control groups. These results were in agreement with that of De Pergola et al. (1997) and Gomez et al. (2002).

In this work fibrinogen was associated with BMI and WHR, and there was a strong positive correlation between fibrinogen and serum leptin. This results were in agreement with Comez et al. (2002).

\section{Conclusion}

Increased body fat mainly (abdominal fat) is associated with increased concentrations of cardiovascular risk factors. Plasma concentration of the prothrombotic factors are increased in obese subjects, as compared to non-obese controls, leptin seemed to be involved in this elevation and emerged as a predictor of circulating PAI-1, vWF and fibrinogen concentration. Increased PAI-1 expression in obese subjects can direct influence vessel wall remodeling and play an important role in the development of athrothrombosis by decreasing fibrin degradation.

\section{References}

1. Akira H; Kenji N; Youshi N and AKirhiro MY (1997): Relationship between concentration of serum leptin and fetal growth. J Clin Endocrinol Metab; 82 (10): 3281-3284. 
2. Blann A and McCllum C (1994): Von Willebrand factor, endothelial cell damage and athrosclerosis. Eur J Vasc Surg; 8 (1): 10-15.

3. Booth N; Sampson A; Bennett B and MacGregor I (1988): Plasminogen activator inhibitor 1 in plasma and platelets. $\mathrm{Br} \mathbf{J}$ Haematol; 70: 327.

4. Cianflone K; Maslowska $M$ and Sniderman A (1995): The acylation stimulating protein-adipsin system. Int J Obes; 19 (Suppl.1): S34- S38.

5. De Pergola G and Pannacciulli N (2002): Coagulation and fibrinolysis abnormalities in obesity. J Endocrinol Invest; 25 (10): 899-904.

6. De Pergola G; Dmetrio V and Giorgino F (1997): Increase in both prothrombotic and antithrombotic factor in obese premenopausal women: Relationship with body fat distribution. Int J Obes Relat Metab Disord; 21 (7): 527-535.

7. Gomez AJ; Salvador J; Paramo J, et al. (2002): Involvement of leptin in the association between percentage of body fat and cardiovascular risk factors. Clin Biochem; 35 (4): 315-20.

8. Guagnano MT; Romano M; Falco A; Nutini M; Marinopiccoli M; Manigrasso MR; Basili S and Dovi G (2003): Leptin increase is associated with markers of the hemostatic system in obese healthy women. J Thromb Haemost; 1 (11): 2330-4.

9. Hanque $Z$ and Rahman MA (2003): Serum leptin levels in females patients with NIDDM. J Coll Physicians Surg Pak; 13 (3): 130-134.

10. Juhan-Vague I; Alessic MC and Morange PE (2000): Hypofibrinolysis and increased PAI-1 are link atherothrombosis via insulin resistance and obesity. Am Med; 32 (Suppl.1): 78-84.

11. Karl JG and Hymsfield (1987): Morbid obesity; definitions, epidemiology and methodological problems. Gastroenterol Clin North Am; 16: 197-205.

12. Kockx M; Teenes R; Seidelly J; Princen HM and Kooistr A (1999): Relationship between visceral fat and PAI-1 in overweight men and women before and after weight loss. Thromb Haemost;82(5):1490-6.

13. Kuczmarski RJ; Flegal KM and Cambell SM (1994): Increasing prevelance of overweight among us adults. JAMA; 272: 205211.

14. Liuzzi A; Saqvia G; Tagliaferri M; Lucantoni R; Bers ME; Petrone ML; De Medici C and Viberti GC (1999): Serum leptin concentration in moderate and severe obesity: Relationship with clinical, anthropometric and metabolic factors. Int $\mathrm{J}$ Obes Relat Metab Disord; 23 (10): 1066-73.

15. Lowenstein J; Quiroz $\mathbf{C}$ and Montano $\mathbf{O}$ (2004): Overweight is not a limitation for coronary flow measurements by transthoracic Doppler echocardiography. Echocardiograpohy; 21 (2): 208-9.

16. Maffei M; Halaas J; Ravussin E; Pratley RE; Lee GH; Zhang Y and Fei H (1995): Leptin levels in human and rodent: Measurement of plasma leptin and ob RNA in obese and weight reduced subjects. Nat Med; p. 1155-1161.

17. Mavri A; Alessn MC; Bastelica D; GellGeorgelin OF; Sentocnik JI; Stegnar M and Juhon-Vague I (2001): Subcutaneous abdominal, but not femoral fat expression of plasminogen activator inhibitor (PAI-1) is related to plasma PAI-1 levels and insulin resistance and decrease after weight loss. Dibatologia; 44 (11): 2025-31.

18. Miller GD; Frost R and Olive J (2001): Relation of plasma leptin concentrations to sex, body fat, dietary intake, and peak oxygen uptake in young adult women and men. Nutrition; 17 (2): 105-11.

19. Mutch NJ; Wilson HM and Broth NA (2001): Plasminogen activator inhibitor-1 and haemostasis in obesity. Proc Nutr Soc; 60 (3): 341-7.

20. Naveau S; Giraud V; Barotto E, et al. (1997): Excess weight risk factor for alcoholic liver disease. Hepatology; 25: 108-111.

21. Pascual M; Pascual DA; Soria F; Vicente T; hernandz AM; Taber FJ and Valde's MV (2003): Effects of isolated obesity on systolic and diastolic left ventricular function. Heart; 89: 1152-1156.

22. Poirier P and Despres JP (2003): obesity and cardiovascular disease. Med Sci (Paris); 19 (10): 943-9.

23. Porreca E; Difebbo C; Fusco L; Movetta V; Dinisie $M$ and Cuccurullo F (2004): Soluble thrombomodulin and vascular adhesion molecule-1 are associated to leptin plasma level in obese women. Atherosclerosis; 172 (1): 175-80.

24. Romano M; Guagnano MT; Pacini G; Vigneri S; Fal M; Marinopiccoli M; Manigrasso MR; Basili S and Davi G (2003): Association of inflammation markers with impaired insulin sensitivity and coagulative activation in obese healthy women. J Clin Endocrinol Metab; 88 (11): 5321-6. 


\section{Hamdia Ezzat et al}

25. Sendecor GW and Cochran GW (1968): Statistical methods: Sixth edition. Iow State, University Press. Am IOW, USA.

26. Soderberg S; Olsson T; Eliasson M; Johnson $O$ and Ahro M (1999): Plasma leptin levels are associated with abnormal fibrinolysis in men and potmenopausal women. J Intern Med; 245 (5): 533-43.

27. Sudi Km; Gallestl S; Weinhandl G; Muntean W and Borkenstein MH (2000): Relationship between plasminogen activator inhibitor-1 antigen, leptin and fat mass in obese children and adolescents. Metabolism; 49 (7): 890-5.
28. Sundell IB; Nilsson TKJ; Hallmans G and Nygren $C$ (1988): The effect of body build, diet and endocrine fat on the extrinsic fibrinolytic system in healthy young women. Scand J Clin Lab Invest; 48 (6): 557-64.

29. Weyer C; Yudkin JS; Stehouwer CD; Schalkuijk CC; Pratley RE and Tataranni PA (2002): Humoral markers of inflammation and endothelial dysfunction in relation to adiposity and in vivo insulin action in pima Indians. Atherosclerosis; 161 (1): 233-42. 


\section{مستوى اللبتين والعوامل المحفزة على التخثر في الأشخاص المصابين بالسمنة}

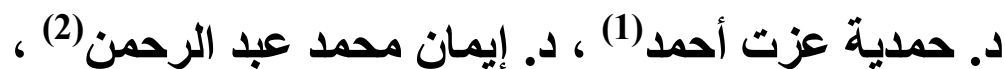

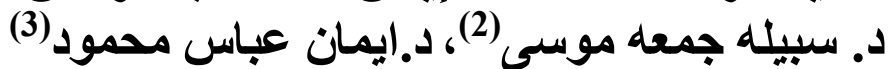

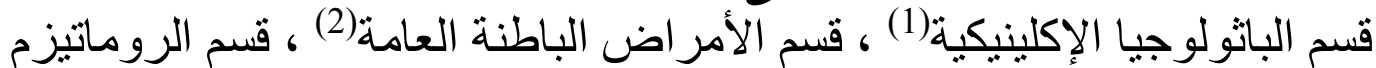

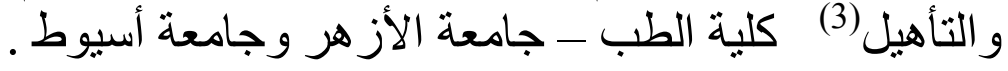

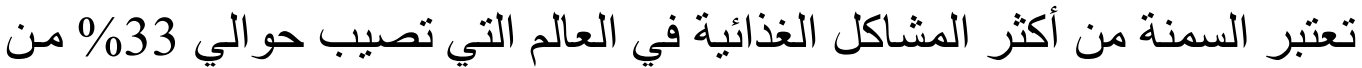

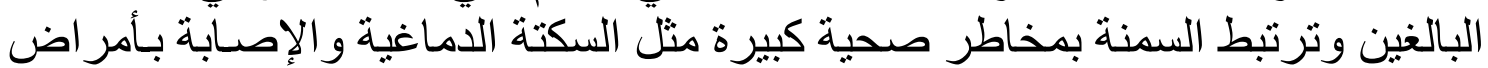
القلب الثريانية و البول السكري.

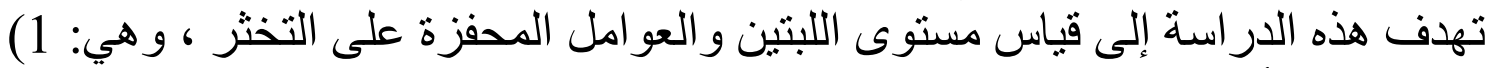

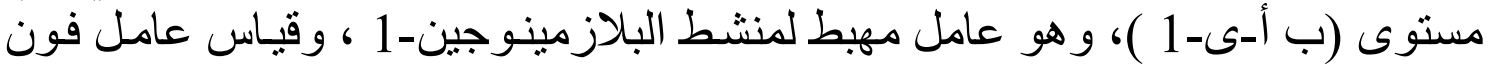
فوليير اند ، وقياس الفيبرنوجين ودر اسة علاقتهم مع السمنة ونسبة الدهون بالجسم للدى

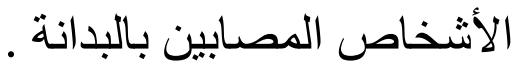

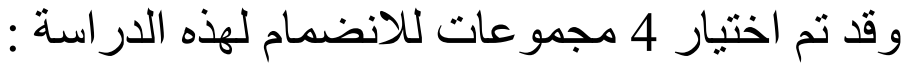

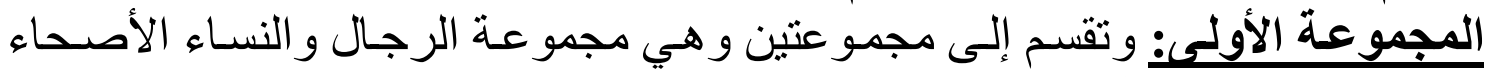
(المجمو عنان الضنابطتان) المجموعة الثانية : و هي مجمو عة من السيدان النيات البدينات.

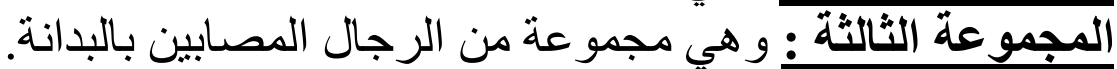

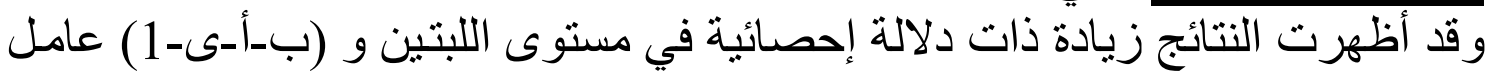

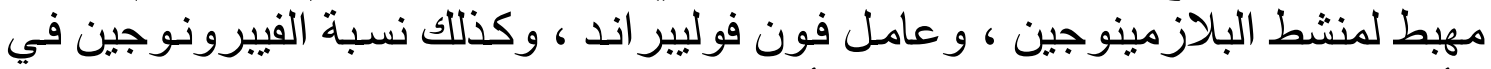

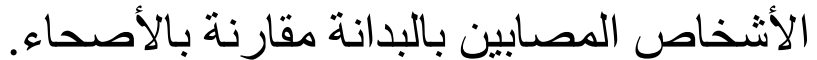

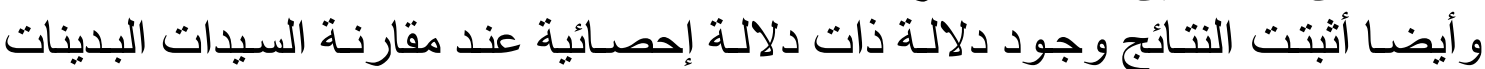

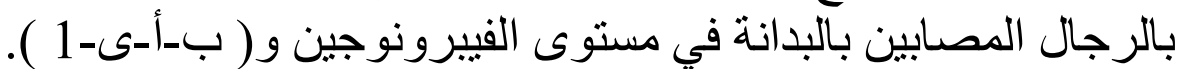

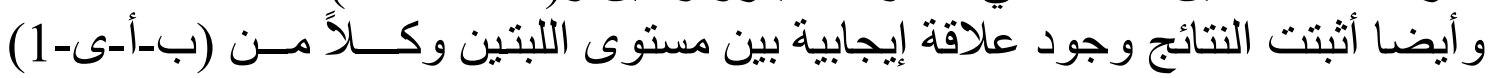

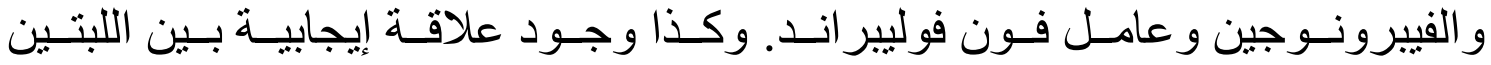
و الكوليسترول و الدهون الثناثية. 